\title{
PERANAN SIARAN TELEVISI EDUKASI DALAM MENDUKUNG TERCIPTANYA SUMBER DAN MOTIVASI BELAJAR BAGI SISWA SMP DI YOGYAKARTA
}

\section{THE ROLE OF THE TELEVISI EDUKASI BROADCAST IN SUPPORTING THE LEARNING RESOURCE CREATION AND THE LEARNING MOTIVATION OF THE STUDENTS IN YOGYAKARTA CITY}

\author{
Muhammad Ragil Kurniawan, Abdul Gafur \\ Universitas Ahmad Dahlan, FIS Universitas Negeri Yogyakarta \\ ragilkur@yahoo.com, agafur@gmail.com
}

\begin{abstract}
Abstrak
Penelitian ini bertujuan untuk mengungkap peranan siaran televisi edukasi (TVe) sebagai sumber belajar dan motivasi belajar bagi siswa SMP di Kodya Yogyakarta. Penelitian menggunakan metode gabungan (mixed method) yaitu penelitian kuantitatif jenis survei diikuti dengan penelitian kualitatif. Pengumpulan data kuantitatif dilakukan dengan menggunakan angket. Sedangkan pengumpulan data kualitatif menggunakan metode wawancara mendalam dan observasi. Data kuantitatif dianalisis menggunakan analisis deskriptif, sedangkan data kualitatif dianalisis menggunakan model Miles dan Huberman. Populasi penelitian adalah 17 SMP di Kodya Yogyakarta. Hasil penelitian menunjukkan: (1) Siaran TV Edukasi belum memberikan peran yang signifikan dalam meningkatkan sumber belajar bagi siswa SMP di Kodya Yogyakarta. (2) Siaran TV Edukasi belum berperan yang signifikan dalam meningkatkan motivasi belajar bagi siswa SMP di Kodya Yogyakarta.
\end{abstract}

Kata kunci: televisi edukasi (TVe), sumber belajar, motivasi belajar. 


\section{Pendahuluan}

Pendidikan dan teknologi merupakan dua hal yang saling berjalan beriring. Pertumbuhan teknologi instruksional mengikuti tahap pertumbuhan dari masyarakat tradisional ke kebudayaan teknologi tinggi. Berbicara tentang produk teknologi beserta kaitannya dengan pembelajaran, televisi (TV) merupakan salah satu produk teknologi modern yang telah mendukung peran teknologi dalam konteks memecahkan masalah pembelajaran.

Dari segi konteks penggunaannya, media televisi di Indonesia telah menjadi bagian dari kehidupan sebagian besar masyarakat. Televisi memberikan imbas media yang luar biasa besar bagi kehidupan masyarakat (Sunardian Wirodono, 2005, p.viii). Hasil research yang dilakukan oleh AC Nielsen Media Research menyebutkan bahwa pada tahun 2003 penetrasi media televisi pada masyarakat indonesia telah mencapai 90,7\% Hal ini mengindikasikan bahwa media televisi telah menjadi media keluarga yang tidak lagi melihat sekat sosial-ekonomi maupun geografis.

Televisi adalah media yang sangat potensial, yang tidak saja untuk menyampaikan informasi tetapi juga membentuk perilaku seseorang. Baik itu membentuk perilaku ke arah positif maupun negatif, disengaja ataupun tidak. Gatut Priyowidodo (2008, p.57) menyebutkan bahwa sebagai media audio visual TV mampu merebut $94 \%$ saluran masuknya pesan-pesan atau informasi ke dalam jiwa manusia yaitu lewat mata dan telinga. Televisi mampu untuk membuat orang pada umumnya mengingat $50 \%$ dari apa yang mereka lihat dan dengar di layar televisi walaupun hanya sekali ditayangkan. Secara umum orang akan ingat $85 \%$ dari apa yang di lihat pada TV, setelah 3 jam kemudian dan 65\% setelah 3 hari kemudian. Secara lebih spesifik lagi kelebihan media televisi terletak pada kombinasi antara gambar, suara, gerakan, dan warna serta bersifat massif (Rusfadia S. Jahja \& Muhammad Irfan, 2006, p.2).
Data yang dirilis Yayasan Kesejahteraan Anak Indonesia (YKAI) pada tahun 2011 menunjukkan bahwa jam belajar formal anak-anak hanya sekitar 850 jam dalam satu tahun, dan ini hanya separuh dari waktu mereka menonton televisi yang mencapai 1.500 jam dalam satu tahun, atau sekitar $35 \mathrm{jam} / \mathrm{minggu}$. Hal ini dikuatkan oleh hasil survei yang dilakukan oleh AC Nielsen media research tahun 2011 menyebutkan pada bulan juni 2011 rata-rata jumlah menonton televisi pada anak adalah 4 jam 30 menit atau 31.5 jam/pekan (Nielsen Newsletter, Juni 2011, p.1).

Hasil survei oleh AGB Nielson Media Research terhadap semua stasiun televisi di 10 kota besar pada tahun 2008 menyebutkan bahwa remaja merupakan penonton yang paling dominan. Pada prime time yaitu antara pukul 20.00 hingga 23.00, persentase remaja yang menonton TV mencapai $14,7 \%$. Sedangkan persentase untuk penonton lain adalah: $10 \%$ untuk penonton dewasa, $10.6 \%$ untuk penonton dewasa muda serta, $13,3 \%$ untuk penonton anakanak. Hal ini menunjukkan bahwa kebiasaan menonton remaja lebih tinggi di sepanjang waktu jika dibandingkan dengan penonton lainnya.

Penelitian yang dilakukan oleh Alva Ayu (2009, p.12) menyebutkan bahwa adanya pengaruh antara tingkat intensitas menonton televisi yang tinggi dengan tingginya imitasi perilaku kekerasan pada anak. Semakin sering seorang anak menonton acara televisi (khususnya) yang bertema kekerasan semakin tinggi pula perilaku dalam tayangan tersebut yang ditiru oleh anak. Penjabaran beberapa data tersebut menunjukkan bahwa televisi memiliki daya tarik tersendiri bagi para remaja sehingga televisi membawa pengaruh, khususnya pengaruh terhadap perilaku kekerasan yang dilihat anak pada tayangan televisi.

Undang Undang No 32 tahun 2002 tentang Penyiaran pada pasal 4 menyebutkan bahwa penyiaran sebagai kegiatan komunikasi massa mempunyai fungsi sebagai media informasi, pendidikan, hibur- 
an yang sehat, kontrol dan perekat sosial. Dengan demikian sesuai dengan undangundang tersebut fungsi siaran televisi tidak hanya sebagai hiburan saja, namun media informasi bahkan media pendidikan masyarakat. Lebih spesifik lagi UU No 32 tahun 2002 pasal 36 ayat 3 menyebutkan bahwa isi siaran dalam tayangan televisi wajib memberikan perlindungan serta pemberdayaan kepada khalayak khusus yaitu anak-anak dan remaja.

Berkebalikan dengan pesan undang-undang di atas, dari tahun 2006 hingga tahun 2008 terdapat sekitar 180 judul sinetron dengan 3.641 episode dan 4.020 jam tayang. Kesemuanya, hanya menggambarkan tema di seputar seks, kekerasan dan mistik, serta glamournya kehidupan elite kota. Hal ini dikuatkan oleh Agus Sudibyo (2009, p.xxxviii) yang menyatakan:

Ranah publik media, khususnya media penyiaran sekadar menjadi ranah komersial. Semakin sulit untuk menjadikan ranah publik media sebagai arena public civility, karena hampir tidak ada kekuatan yang mampu menghambat laju transformasi media sebagai sepenuhnya ranah komersial. Dan ketika produk media menjadi sepenuhnya komoditas komersial, pembentukan watak sosial suatu masyarakat melalui media semakin tidak lagi di tentukan oleh prinsip-prinsip kewargaan, melainkan oleh prinsip-prinsip konsumsi.

Sunardian Wirodono (2005, p.75) dalam bahasa lain menyimpulkan, karena bisnis televisi berangkat dari logika bisnis maka urusan moral dan pendidikan untuk masyarakat menjadi dikesampingkan.

Tidak bisa dipungkiri bahwa beberapa kondisi nyata menyebutkan materi siaran yang ada pada televisi swasta komersial memang masih jauh dari sebagaimana yang diharapkan oleh undangundang Penyiaran No. 32 tahun 2002 khususnya pasal 32. Oleh karena itu pemerintah melalui Pusat Teknologi Informasi dan Komunikasi Pendidikan (Pustekkom) berinisiatif menyelenggarakan sebuah siaran yang terfokus pada siaran pendidikan yaitu melalui stasiun televisi pendidikan yang bernama Televisi Edukasi (TVE).

Salah satu tujuan hadirnya TVE yang operasionalnya dibiayai oleh anggaran negara adalah untuk menjawab kendala yang ada pada materi siaran televisi swasta komersial yang sarat dengan urusan bisnis serta minim konten moral dan pendidikan. Hal itu tersurat dalam salah satu visi dan misi yang dibawa oleh TVE yaitu mencerdaskan masyarakat, memberi tauladan, menyebarluaskan informasi dan kebijakan pendidikan dan mewujudkan masyarakat gemar belajar (Pustekkom, 2007, p.4). Dengan demikian potensi serta kelebihan yang dimiliki oleh media televisi secara umum dapat terwadahi secara bijak untuk dimanfaatkan dalam dunia pendidikan. Salah satu manfaat yang dari hadirnya TVE, sebagaimana yang tertuang dalam selayang pandang TVE, adalah untuk memotivasi siswa dalam belajar dan sebagai sumber belajar khususnya bahan ajar yang bermutu (Pustekkom, 2007, p.5).

Misi TVE dalam usaha mewujudkan sumber belajar yang bermutu layak untuk mendapatn dukungan penug dari stakeholder pendidikan. Pada lingkungan pembelajaran, sumber belajar menjadi salah satu faktor yang dominan dalam proses mempercepat internalisasi pengetahuan ke diri peserta didik. Dalam teknologi pendidikan, pemecahan masalah belajar nampak dalam bentuk semua sumber belajar yang didisain, dipilih atau di manfaatkan. Siaran televisi pendidikan merupakan salah satu bentuk dari sumber belajar yang direncanakan keberadaannya. Salah satu peran penting Televisi Edukasi, yang mendeklarasikan diri sebagai televisi pendidikan, adalah sebagai sumber belajar bagi peserta didik dan pendidik. Oleh karena itu, diperlukan pembuktian ilmiah terhadap seberapa besar peranan Televisi Edukasi sebagai salah satu sumber belajar dalam mendukung pembelajaran peserta didik sekaligus menjadi pilihan pendidik. 
Yunanto (2004, p.20) menyatakan bahwa sumber belajar yang terkoordinir dengan baik akan mampu mebangkitkan minat dan motivasi siswa dalam belajar. Motivasi belajar yang tinggi akan mampu menunjang prestasi belajar siswa. Bahkan Hamzah B. Uno (2011, p.27) mengemukakan bahwa belajar tidak dapat terjadi jika tidak ada motivasi dalam diri seseorang untuk belajar. Menurut Uno (2011, p.23) indikator motivasi belajarantara lain: (1) adanya hasrat dan keinginan berhasil; (2) Adanya dorongan dan kebutuhan dalam belajar; (3) Adanya harapan dan cita-cita masa depan; (4) Adanya penghargaan dalam belajar; (5) Adanya kegiatan yang menarik dalam belajar; (6) Adanya lingkungan belajar yang kondusif sehingga memungkinkan siswa dapat belajar dengan baik.

Dengan demikian diperlukan pembuktian empiris tentang peran TVE sebagai sumber belajar yang efektif, perlu juga ada pembuktian tentang keberadaan siaran TVE dalam membangkitkan motivasi bagi peserta didik, khususnya di wilayah Kodya Yogyakarta. Berdasarkan uraian di atas, peneliti merasa terdorong untuk melakukan pengkajian dalam kegiatan penelitian dengan melakukan survei terhadap pelajar SMP di Kodya Yogyakarta. Penelitian ini bertujuan untuk mengetahui peranan siaran televisi edukasi dalam mendukung terciptanya sumber belajar dan motivasi belajar bagi siswa SMP di Kodya Yogyakarta.

\section{Metode Penelitian}

Penelitian ini menggunakan pendekatan mixed methods tipe Sequential QUANqual (Tashakkori \& Teddie, 2010, p.73) yaitu antara penelitian kuantitatif jenis survei dengan penelitian kualitatif. Metode gabungan (mixed method) dalam penelitian ini menitik beratkan pada pendekatan kuantitatif jenis survei. Penelitian kualitatif digunakan sebagai tindak lanjut dan hanya sebagai pendalaman dari data kuantitatif hasil survei yang telah diperoleh. Penelitian utamanya berbentuk penelitian kuanti- tatif jenis survei sedangkan penelitian pendukungnya mengguanakan jenis deskriptif kualitatif.

Situs penelitian adalah wilayah Kotamadya Yogyakarta yang terbagi menjadi 14 kecamatan. Populasi penelitian ini adalah Sekolah Menengah Pertama (SMP) se-Kodya Yogyakarta yang ditunjuk oleh Kemendikbud Propinsi D.I Yogyakarta untuk mendapat bantuan perangkat keras televisi dan digunakan dalam pemanfaatan siaran TVE dalam pembelajaran. Sesuai data dari Kementrian Pendidikan dan Kebudayaan Propinsi DI. Yogyakarta, terdapat 17 SMP negeri maupun swasta di wilayah kodya Yogyakarta yang secara resmi mendapat bantuan perangkat keras televisi. SMP yang dimaksud didalamnya tidak termasuk MTs ataupun SLB dan Paket B. Jadi populasi dalam penelitian ini terdiri dari 17 sekolah.

Teknik pengambilan sampel yang digunakan adalah multistage random sampling dengan cara proportional propability. Pengambilan sampel dilakukan tiga tahapan sebagai berikut: Pertama, populasi yang ada dikelompokkan ke dalam kategori akreditasi sekolah yang didapat (akreditasi A, B atau C). Kedua, dari masing-masing kelompok akreditasi (A, B dan C) di ambil sampel secara acak, dengan perbandingan antara populasi dengan sampel $3: 1$. Ketiga: dari satu sekolah sampel dipilih kelas 9 dengan pertimbangan bahwa siswa-siswa kelas IX relatif lebih mapan dan lebih lama menggunakan media TV edukasi di sekolah dibandingkan dengan siswa-siswa kelas VII dan VIII, serta dianggap lebih memahami gambaran tentang faktor-faktor yang diteliti. Berdasarkan tahapan penentuan sampel tersebut, diperoleh 6 sekolah sampel, yaitu 1 sekolah sampel mewakili kelompok sekolah akreditasi A, tiga sekolah sampel mewakili kelompok sekolah akreditasi B, dan 2 sekolah sampel mewakili kelompok sekolah akreditasi C.

Teknik pengumpulan data yang digunakan meliputi: kuesioner, wawancara dan telaah dokumen. Kuesioner digunakan untuk menggali data tentang pendapat 
siswa SMP di kodya Yogyakarta tentang peran siaran TV edukasi sebagai sumber belajar dan motivasi belajar. Kuesioner disusun sendiri oleh peneliti dengan sebelumnya dilakukan uji validitas isi dan validitas konstruk untuk menguji keandalan instrumen. Kuesioner berisi cakupan indikator sumber belajar dan motivasi belajar. Indikator sumber belajar terdiri dari: (a) produktivitas pembelajaran; (b) meningkatkan keinginan belajar; (c) pembelajaran yang lebih individual; (d) memudahkan dalam belajar; dan (e) pemberian dasar ilmiah. Indikator motivasi belajar terdiri dari: a) hasrat dan keinginan untuk berhasil; (b) harapan dan cita-cita masa depan; (c) kegigihan dalam belajar; (d) kepuasan dalam belajar; (e) minat belajar; dan (f) perhatian dalam belajar

Dalam instrumen kuesioner yang sama juga terdapat pertanyaan tentang durasi pemanfaatan siaran siaran TV edukasi oleh siswa. Dengan kata lain, terdapat acuan rata-rata waktu yang digunakan oleh siswa untuk menyaksikan siaran TV edukasi di tiap pekannya. Kategori yang digunakan untuk memetakan durasi pemanfaatan siaran TV edukasi per pekannya adalah (a) $0-1$ jam pelajaran, (b) 2-3 jam pelajaran, (c) 3-4 jam pelajaran, (d) 6-7 jam pelajaram dan (e) lebih dari 7 jam pelajaran. Tiap skala mempunyai nilai: $\mathrm{a}=$ $0, b=1, c=2, d=3, e=4$.

Wawancara dilakukan untuk memperdalam informasi dari data yang diperoleh melalui kuesioner. Wawancara dimaksudkan untuk memperoleh informasi tentang penyebab tidak optimalnya pemanfaatan siaran TV edukasi oleh sekolah penerima bantuan perangkat dari progran TV edukasi. Wawancara dilakukan terhadap 6 informan, diantaranya: (a) masingmasing 1 orang kepala sekolah mewakili kelompok sekolah akreditasi A, B dan C; (b) masing-masing 1 orang guru mata pelajaran mewakili kelompok sekolah akreditasi A, B, dan C. Selain pedoman wawancara juga digunakan checklist atas kepemilikan media dan sumber belajar yang ada di sekolah sebagai data pen- dukung atas hasil wawancara yang dilakukan.

Analisis data dilakukan secara kuantitatif dan kualitatif sesuai dengan jenis data yang dikumpulkan. Data kuantitatif yang dikumpulkan melalui kuesioner dianalisis secara kuantitatif dengan teknik statistik rerata, median, modus, rentang skor, simpangan baku, dan persentase. Data hasil wawancara dan telaah dokumentasi dianalisis secara kualitatif dengan teknik analisis deskriptif kuantitatif dari Miles dan Huberman.

\section{Hasil Penelitian dan Pembahasan}

Hasil Kuesioner

Uraian data dalam penelitian ini akan dikelompokkan menjadi dua kategori, yaitu kategori sumber belajar dan kategori motivasi belajar. Masing masing kategori terbagi menjadi tiga penggolongan, yaitu kelompok sekolah akreditasi A, kelompok sekolah akreditasi B, dan kelompok sekolah akreditasi C. Dalam kategori sumber belajar, terinci lagi menjadi 5 (lima) kelompok kecil, sebagaimana jumlah indikator yang membentuk komponen sumber belajar. Sedangkan kategori motivasi belajar terinci lagi menjadi 6 (enam) kelompok kecil, sebagaimana jumlah indikator yang membentuk komponen motivasi belajar.

Adapun hasil perolehan data tentang peranan siaran TV edukasi dalam mendukung terciptanya sumber belajar dan motivasi belajar pada Sekolah Menengah Pertama (SMP) di wilayah Kodya Yogyakarta dapat ditunjukkan sebagai berikut:

\section{Sumber Belajar}

Data gabungan dari tiap-tiap kelompok akreditasi yang merupakan akumulasi keseluruhan data sampel penelitian untuk kategori sumber belajar dapat terangkum dalam grafik 1 yang berisikan gabungan dari seluruh sekolah sampel sebagaimana disajikan pada Gambar 1 . 


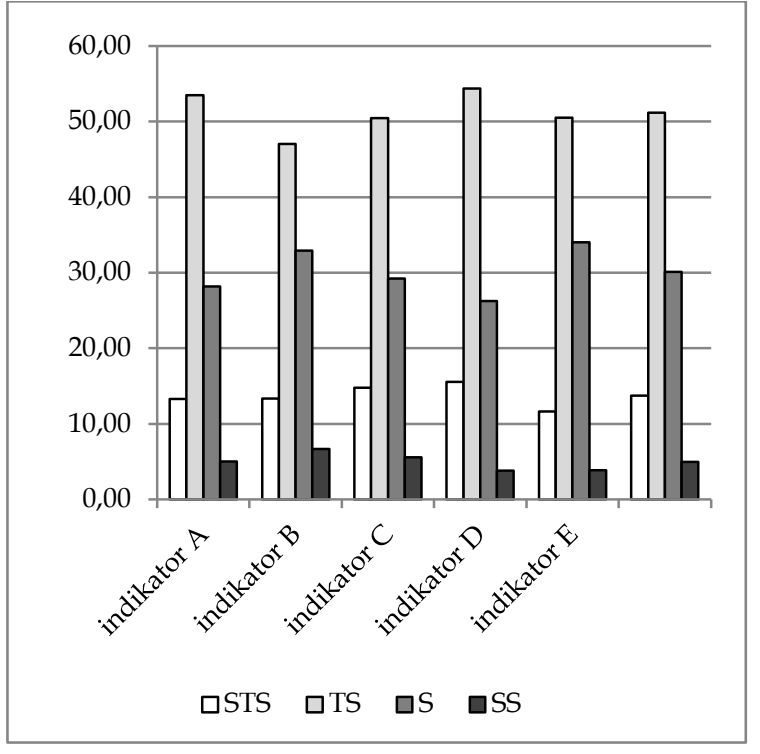

Gambar 1. Persentase Sumber Belajar pada Seluruh Sekolah Sampel

(akumulasi dari akreditasi A, B, dan C)

Data peran siaran TV edukasi sebagai sumber belajar menurut siswa SMP di Kodya Yogyakarta terangkum dalam grafik di atas, namun dengan lebih rinci dapat dijabarkan pada masing-masing indikator sebagai berikut:

Dalam indikator produktivitas belajar, terdapat $13,30 \%$ siswa menyatakan sangat tidak setuju (STS); 53,49\% siswa menyatakan tidak setuju (TS); $28,20 \%$ siswa menyatakan setuju (S); dan 5,02\% siswa menyatakan sangat setuju (SS) bahwa siaran TV edukasi mendukung produktivitas belajar siswa.

Dalam indikator produktivitas belajar, terdapat $13,33 \%$ siswa menyatakan sangat tidak setuju (STS); 47,05\% siswa menyatakan tidak setuju (TS); 32,91\% siswa menyatakan setuju (S); dan 6,70\% siswa menyatakan sangat setuju (SS) bahwa siaran TV edukasi ikut serta dalam meningkatkan gairah belajar siswa.

Dalam indikator produktivitas belajar, terdapat $14,78 \%$ siswa menyatakan sangat tidak setuju (STS); 50,45\% siswa menyatakan tidak setuju (TS); $26,20 \%$ siswa menyatakan setuju (S); dan 5,56\% siswa menyatakan sangat setuju (SS) bahwa siaran TV edukasi memberikan visi pembelajaran individual bagi siswa.
Dalam indikator produktivitas belajar, terdapat $15,57 \%$ siswa menyatakan sangat tidak setuju (STS); 54,35\% siswa menyatakan tidak setuju (TS); $26,27 \%$ siswa menyatakan setuju (S); dan 3,82\% siswa menyatakan sangat setuju (SS) bahwa siaran TV edukasi menjadikan kegiatan belajar siswa menjadi lebih mudah.

Dalam indikator produktivitas belajar, terdapat $11,62 \%$ siswa menyatakan sangat tidak setuju (STS); 50,51\% siswa menyatakan tidak setuju (TS); 34,01\% siswa menyatakan setuju (S); dan 3,87\% siswa menyatakan sangat setuju (SS) bahwa siaran TV edukasi memberikan dasar ilmiah bagi siswa.

\section{Motivasi Belajar}

Data gabungan dari tiap-tiap kelompok akreditasi yang merupakan akumulasi keseluruhan data sampel penelitian untuk kategori motivasi belajar dapat terangkum dalam grafik 2 yang berisikan gabungan dari seluruh sekolah sampel sebagaimana disajikan pada Gambar 2 .

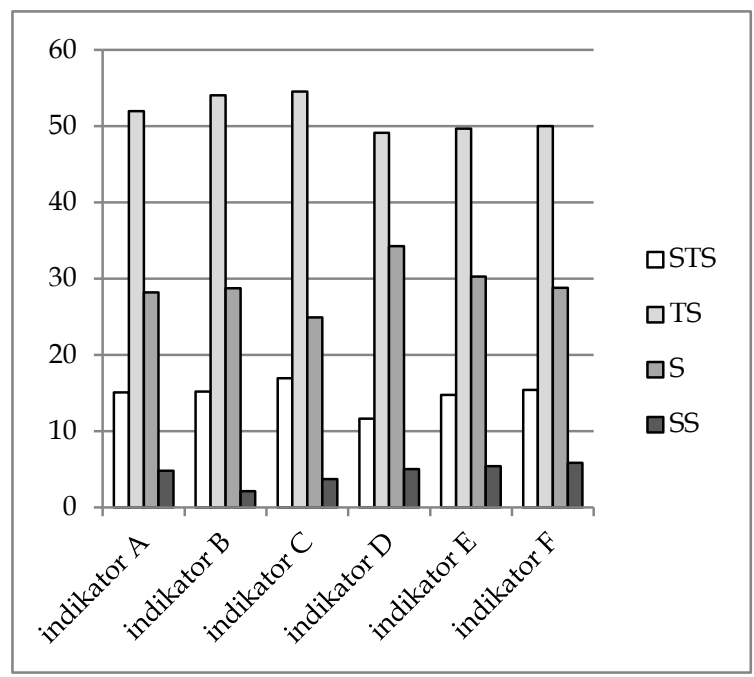

Gambar 2. Persentase Motivasi Belajar pada Seluruh Sekolah Sampel

(akumulasi dari akreditasi A, B, dan C)

Data peran siaran TV edukasi sebagai motivasi belajar menurut siswa SMP di Kodya Yogyakarta terangkum dalam grafik diatas, namun dengan lebih rinci dapat dijabarkan pada masing-masing indikator sebagai berikut. 
Dalam indikator adanya hasrat dan keinginan untuk berhasil, terdapat $15,07 \%$ siswa menyatakan sangat tidak setuju (STS); 51,97\% siswa menyatakan tidak setuju (TS); 28,16\% siswa menyatakan setuju (S); dan 4,81\% siswa menyatakan sangat setuju (SS) bahwa siaran TV edukasi mendorong munculnya hasrat dan keinginan untuk berhasil bagi siswa.

Dalam indikator adanya dorongan dan kebutuhan belajar, terdapat 15,17\% siswa menyatakan sangat tidak setuju (STS); 54,02\% siswa menyatakan tidak setuju (TS); $28,72 \%$ siswa menyatakan setuju (S); dan 2,09\% siswa menyatakan sangat setuju (SS) bahwa siaran TV edukasi memicu munculnya dorongan dan kebutuhan belajar bagi siswa.

Dalam indikator adanya harapan dan cita-cita masa depan, terdapat 16,90\% siswa menyatakan sangat tidak setuju (STS); 54,51\% siswa menyatakan tidak setuju (TS); $24,89 \%$ siswa menyatakan setuju (S); dan 3,70\% siswa menyatakan sangat setuju (SS) bahwa siaran TV edukasi mendorong munculnya harapan dan cita-cita masa depan bagi siswa.

Dalam indikator adanya penghargaan dalam belajar, terdapat $11,61 \%$ siswa menyatakan sangat tidak setuju (STS); 49,11\% siswa menyatakan tidak setuju (TS); $34,24 \%$ siswa menyatakan setuju (S); dan $5,03 \%$ siswa menyatakan sangat setuju (SS) bahwa siaran TV edukasi mendorong munculnya penghargaan dalam belajar bagi siswa.

Dalam indikator adanya kegiatan yang menarik, terdapat $14,73 \%$ siswa menyatakan sangat tidak setuju (STS); 49,64\% siswa menyatakan tidak setuju (TS); 30,23\% siswa menyatakan setuju (S); dan 5,40\% siswa menyatakan sangat setuju (SS) bahwa siaran TV edukasi mendorong munculnya kegiatan yang menarik dalam belajar bagi siswa.

Dalam indikator adanya lingkungan belajar yang kondusif, terdapat 15,40\% siswa menyatakan sangat tidak setuju (STS); 49,98\% siswa menyatakan tidak setuju (TS); $28,79 \%$ siswa menyatakan setuju (S); dan 5,84\% siswa menyatakan sangat setuju (SS) bahwa siaran TV edukasi mendorong munculnya lingkungan belajar yang kondusif bagi siswa.

\section{Intensitas Penggunaan Siaran TV Edukasi}

Data intensitas penggunaan siaran TVE pada SMP di Kodya Yogyakarta yang diperoleh melali survei adalah sebagai berikut:

Tabel 1. Intensitas penggunaan siaran TV edukasi

\begin{tabular}{|c|c|c|c|}
\hline Kategori & $\begin{array}{l}\text { Sekolah } \\
\text { Akred A }\end{array}$ & $\begin{array}{l}\text { Sekolah } \\
\text { Akred B }\end{array}$ & $\begin{array}{l}\text { Sekolah } \\
\text { Akred C }\end{array}$ \\
\hline $\begin{array}{l}\text { Durasi penggunaan } \\
\text { siaran TV Edukasi } \\
\text { (berapa kali per } \\
\text { pekan) }\end{array}$ & $\begin{array}{r}\text { skala } 1,00 \\
(0-1 \text { kali) }\end{array}$ & $\begin{array}{c}\text { Skala } 1,00 \\
(0-1 \text { kali) }\end{array}$ & $\begin{array}{c}\text { Skala 1,32 } \\
\text { (2-3 kali) }\end{array}$ \\
\hline
\end{tabular}

Data dalam Tabel 1 telah menunjukkan bahwa pada keseluruhan tingkat akreditasi sekolah, pemanfaatan siaran TVE dalam menunjang kegiatan pembelajaran di sekolah masih sangat rendah. Jika dari ketiga kelompok sampel tersebut di total, maka rerata durasi dari intensitas penggunaan siaran TVE adalah 1,11 atau masuk kategori rendah. Dengan kata lain masing masing sekolah sampel rata-rata maksimal menggunakan 2 jam pelajaran tiap pekannya.

\section{Hasil Wawancara}

\section{Mekanisme pemanfaatan siaran TV edukasi}

Berdasarkan hasil wawancara dengan 3 informan kepala sekolah dan 3 informan guru mata pelajaran, diketahui bahwa mekanisme pemanfaatan siaran TVE dilakukan jika ada kelonggaran waktu pada mata pelajaran tertentu atau saat ada kekosongan jam pelajaran yang guru pengampunya berhalangan hadir. Hal ini dikuatkan dengan hasil analisis dokumen yang menyebutkan bahwa sangat sedikit mata pelajaran yang disiarkan dalam TVE yang jadwalnya sesuai dengan jadwal yang ada di sekolah.

Hasil wawancara dengan seorang kepala sekolah menyebutkan bahwa pada awal perjalanan program yaitu tahun 2007- 
2008 memang sekolah berusaha keras untuk benar-benar memanfaatkan bantuan perangkat TV untuk menyaksikan siaran TVE bagi siswa. Namun dengan berjalannya waktu usaha yang maksimal tidak membuahkan hasil yang seimbang dan ahirnya sekolah mulai beralih fokus pada optimalisasi sumber belajar lain.

\section{Kendala pemanfaatan siaran TV Edukasi}

Berdasarkan wawancara yang dilakukan terhadap kepala sekolah dan guru diketahui bahwa rendahnya pemanfaatan siaran TVE disebabkan banyak faktor. Beberapa faktor utama adalah, susahnya menyesuaikan jadwal pelajaran yang ada di sekolah dengan jadwal siaran TVE yang tepat dengan mata pelajaran di sekolah.

Selain persoalan sinkronisasi jadwal, penempatan waktu untuk jadwal siar matapelajaran tingkat SMP yang ada lebih sering di letakkan pada pagi hari pukul 07.00 sd pukul 08.00 yang merupakan kegiatan perdana pada pembelajaran di sekolah. Sedangkan oleh pihak sekolah kegiatan perdana pagi hari di sekolah lebih dimaksimalkan dengan kegiatan tatap muka langsung antara siswa dengan guru karena kondisi psikologis anak masih sangat fres. Hal ini memunculkan dilema di pihak penamggung jawab sekolah.

\section{Solusi yang diharapkan}

Terkait beberapa solusi yang diharapkan, terdapat beberapa harapan mulai yang sederhana hingga yang sangat mendasar diantaranya: (1) Fleksibilitas jam tayang menjadi salah satu harapan yang muncul guna mengatasi kendala pilihan waktu (wawancara, 19 Desember 2012). Fleksibilitas yang dimaksud bisa berupa penyampaian materi yang sama di ulas secara berulang namun dengan metode yang berfariasi. Pilihan fleksibilitas lain adalah meniadakan seluruh acara non formal di waktu jam belajar formal dan diisi dengan seluruh acara untuk pendidikan formal; (2) Membiarkan siaran TVE menjadi ranah pendidikan non-formal dan in-formal (wawancara, 13 Desember
2012). Karakter TVE sebagai media massa dengan cakupan audien yang sangat luas yang berujung kurang efektif dalam hal kedalaman dan keberagaman materi menjadikan ide ini muncul; (3) Terdapat fasilitas tambahan yaitu alat perekam siaran televisi (wawancara, 10 Desember 2012), jadi sewaktu-waktu ada siaran yang sesuai dengan kebutuhan materi pelajaran di sekolah, guru dapat merekam saat siaran TVE berlangsung dan memanfaatkannya dalam pembelajaran di kelas di waktu lain. Ide solusi yang ketiga ini merupakan ide yang paling kongkrit dalam rangka tetap mempertahankan keberadaan siaran TVE.

\section{Pembahasan}

Dari semua data yang terpaparkan pada table 1 dan 2 diketahui bahwa akumulasi persentase yang diperoleh masingmasing komponen adalah: sebanyak $64,86 \%$ responden menyatakan belum merasakan keberadaan siaran TV edukasi sebagai sumber belajar. Responden yang menyatakan siaran TV edukasi telah berperan sebagai sumber belajar hanya sebanyak 35,11\%; Sedangkan untuk komponen motivasi belajar sebanyak 66,35\% responden menyatakan siaran TV edukasi tidak berperan dalam menciptakan motivasi belajar siswa. Responden yang menyatakan siaran TV edukasi telah mendukung terciptanya motivasi belajar siswa hanya sebanyak $33,65 \%$.

Semua data yang terpaparkan di atas menyebutkan bahwa siaran TVE masih belum bisa mendukung terciptanya sumber belajar juga belum bias mendorong munculnya motivasi belajar bagi siswa SMP di Kodya Yogyakarta. Hal ini diperkuat dengan data yang lebih spesifik pada masing-masing sekolah akreditasi dan masing-masing indikator yang kesemuanya data tidak ada yang memberatkan pada pendapat bahwa siaran TVE sebagai pendukung terwujudnya sumber belajar siswa. 
Berdasarkan data tersebut dapat dimaknai bahwa keberadaan siaran TVE belum bisa menjawab persoalan di sekolah tentang kebutuhan sumber belajar. Siaran TVE yang diharapkan mampu menjadi solusi atas keterbatasan sumber belajar di sekolah ternyata belum berperan secara maksimal. Dalam hal peranan pendorong motivasi siswa, TVE juga belum bisa menjawab persoalan di sekolah untuk membangun motivasi belajar siswa. Siaran TVE yang diharapkan mampu menjadi pendorong munculnya motivasi belajar siswa ternyata belum berperan secara maksimal. Kondisi tersebut mengindikasikan bahwa penentuan mekanisme pemanfaatan siaran TVE tidak direncanakan secara utuh dan matang, atau evaluasi terhadap efektifitas program siaran TVE tidak berjalan dengan maksimal. Rendahnya persentase yang cukup merata antara komponen sumber belajar dan motivasi belajar mengindikasikan ada penyebab utama atau terdapat kondisi prasyarat yang tidak berjalan secara wajar.

Salah satu kondisi prasyarat yang dapat digunakan untuk menganalisis peran sebuah media adalah dapat ditilik dari bagaimana intensitas pemanfaatan media pembelajaran tersebut. Data tentang durasi pemanfaatan siaran TVE di sekolah menyebutkan bahwa siaran TVE hanya dimanfaatkan maksimal 2 jam pelajaran per pekan. Rendahnya pemanfaatan tersebut disertai dengan alasan pemanfaatan yang mayoritas untuk mengisi kekosongan guru mata pelajaran, bukan dengan sengaja bertujuan khusus memanfaatkan siaran TVE.

Data yang menyebutkan bahwa siaran TVE hanya dimanfaatkan maksimal 2 jam pelajaran per pekan menjadi indikator kuat penyebab rendahnya peran siaran TVE terhadap penciptaan sumber belajar dan motivasi belajar. Berpijak pada data yang menyebutkan bahwa pemanfaatan siaran TVE yang sangat rendah tersebut, maka fenomena rendahnya peran siaran TVE terhadap penciptaan sumber belajar dan motivasi belajar ini salahsatunya terjadi karena rendahnya pemanfaatan siaran
TVE dalam kegiatan belajar pembelajaran di sekolah. Terkait rendahnya pemanfaatan siaran TV terhadap peran atau dampak yang ditimbulkan, Eka Sulistyadewi (1995, p.23) menyebutkan bahwa dampak siaran televisi berbanding lurus dengan jumlah waktu dan terpaan yang diterima pemirsanya. Artinya, semakin banyak mereka menonton sebuah acara televisi, besar kemungkinan semakin tinggi juga pengaruh yang diperoleh pemirsa lewat acara televisi tersebut.

Dalam ilmu komunikasi terdapat beberapa teori yang membahas tentang dampak dari media massa, salah satunya adalah teori kultivasi. Dalam teori kultivasi ini penonton televisi pada dasarnya terbagi 2 kelompok ekstrim, yaitu penonton berat (heavy viewer) dan penonton biasa (light viewers). Semakin orang menjadi pencandu berat televisi (heavy viewer) maka akan lebih mempengaruhi sikap mereka mengenai objek yang dilihatnya di televisi. Sebaliknya seorang yang bukan pecandu berat televisi (light viewers) sikapnya tidak mudah dipengaruhi oleh tayangan televisi tersebut (Severin \& Tankard Jr, 2010, p.312).

Dengan menggunakan analisa teori kultivasi ini, dapat disimpulkan bahwa tingginya persentase pendapat siswa di Kodya Yogyakarta yang menyatakan bahwa siaran televisi edukasi belum berperan dalam penciptaan sumber belajar dan motivasi belajar adalah salahsatunya disebabkan karena rendahnya durasi pemanfaatan siaran TV edukasi tersebut dalam menunjang proses pembelajaran di lingkungan sekolah. Namun demikian bukan berarti bahwa kesimpulan ini berlaku sebaliknya. Dengan kata lain, tidak bisa secara otomatis sebaliknya disimpulkan bahwa jika durasi pemanfaatan siaran TVE tinggi atau pihak sekolah sering memanfaatkan siaran TVE dalam kegiatan belajar mengajar maka peran siaran TVE terhadap terciptanya sumber belajar dan motivasi belajar juga tinggi. Hal itu masih membutuhkan penelitian lanjutan, karena temuan dalam penelitian ini durasi pemanfaatan siaran TVE yang diperoleh dari 
semua sampel adalah sama, yaitu durasi pemanfaatannya rendah (antara 0 - 2 jam per pekan).

Dari tiap-tiap kelompok sekolah akreditasi terlihat bahwa masing-masing memiliki tingkat perhatian yang berbeda antar indikator dari komponen motivasi belajar dan sumber belajar. Hal ini juga memberikan indikasi bahwa tiap kelompok siswa memiliki sudut pandang, kekhasan dan kebutuhan belajar yang berbeda-beda dan ini yang pada ahirnya disebut bahwa siswa memiliki karakteristik unik yang berbeda-beda (Sardiman, 2007, p.119; Oemar Hamalik, 2008, p.126). Dari perbedaan karakteristik siswa ini Diaz, Pelletier and Provenzo (2006, p.81) menyarankan bahwa perbedaan cara belajar siswa mensyaratkan untuk terciptanya pendekatan pembelajaran yang beragam.

Dari penelusuran lanjutan yang dilakukan oleh peneliti ditemukan beberapa penyebab atas rendahnya pemanfaatan siaran TVE dalam kegiatan belajar mengajar di sekolah, diantaranya:

Pertama, antara jadwa siaran mata pelajaran tertentu dengan jadwal mata pelajaran yang ada di sekolah seringnya tidak tepat secara waktu. Dengan kata lain, saat antara jadwal acara dengan jadwal mata pelajaran saling berselisih hari.

Kedua, jika pihak sekolah hendak menyesuaikan jadwal mata pelajaran di tiap pekannya dengan jadwal mata acara siaran TVE, seringnya sekolah terkendala dengan penyesuaian jadwal bagi guruguru yang jadwal mengajarnya padat dan tidak hanya mengajar di satu sekolahan.

Ketiga, untuk materi tertentu yang mensyaratkan hierarkhi dari penyampaiannya, seperti materi untuk mata pelajaran eksakta, selain dua kendala di atas, penyesuaian sub pokok bahasan antara yang sedang di ajarkan di sekolah dengan apa yang disiarkan pada siaran TVE juga merupakan salah satu persoalan tersendiri. Terlebih setelah diberlakukannya Ujian Nasional, para guru lebih terfokus pada penyelesaian seluruh materi guna menunjang kelulusan anak dalam ujian nasional.
Keempat, sifat siaran TVE yang belum berdiri sendiri, atau masih mengikuti (relay) dengan stasiun TV lain, dalam hal ini TVRI atau ADI TV, tidak jarang menjadi kendala saat tiba-tiba dua stasiun tersebut tidak menyiarkan siaran TVE. Terkecuali jika sekolah memiliki langganan TV kabel atau parabola, sehingga beberapa kendala perubahan jadwal karena relay tidak lagi menjadi hambatan.

Dari beberapa kendala yang peneliti peroleh dari hasil penelusuran lanjutan, yang paling menonjol adalah kendala terkait persoalan teknis memadukan antara jadwal siaran TVE dengan jadwal mata pelajaran yang ada di sekolah. Sebagaimana disampaikan Yusufhadi Miarso (2005, p.386) bahwa kendala utama pemanfaatan media massa dalam pendidikan formal adalah persoalan penjadwalan. Dengan kata lain, kesuksesan pembelajaran menggunakan siaran televisi adalah bergantung pada keahlian serta kematangan persiapan pembelajaran yang dilakukan oleh guru.

\section{Simpulan dan Saran}

Berdasarkan hasil penelitian dan pembahasan yang telah diuraikan pada bab sebelumnya, maka dapat ditarik kesimpulan sebagai berikut:

Siaran TV edukasi belum memberikan peran yang signifikan dalam meningkatkan sumber belajar bagi siswa SMP di Kodya Yogyakarta. Hal ini diindikasikan dengan rendahnya persentase tiap indikator sumber belajar yang keseluruhan indikator menyebutkan bahwa mayoritas siswa SMP di Kodya Yogyakarta belum merasakan keberadaan siaran TV edukasi sebagai salah satu sarana sumber belajar bagi kegiatan belajar. Secara keseluruhan sebanyak $64,86 \%$ responden menyatakan belum merasakan keberadaan siaran TV edukasi sebagai sumber belajar. Responden yang menyatakan siaran TV edukasi telah berperan sebagai sumber belajar hanya sebanyak 35,11\%.

Siaran TV edukasi juga belum berperan yang signifikan dalam meningkatkan motivasi belajar bagi siswa SMP di Kodya Yogyakarta. Hal ini diindikasikan 
dengan rendahnya persentase tiap indikator dari motivasi belajar yang keseluruhan indikator menyebutkan bahwa mayoritas siswa SMP di Kodya Yogyakarta belum merasakan keberadaan siaran TV edukasi sebagai salah satu sarana pendorong munculnya motivasi belajar bagi kegiatan belajar. Secara keseluruhan sebanyak $66,35 \%$ responden menyatakan siaran TV edukasi tidak berperan dalam menciptakan motivasi belajar siswa. Responden yang menyatakan siaran TV edukasi telah mendukung terciptanya motivasi belajar siswa hanya sebanyak 33,65\%.

\section{Daftar Pustaka}

AGBNielson Media Research. (2008). Pembukaan olimpiade beijing 2008 meningkatkan pangsa pemirsa TVRI. Diakses tanggal 7 September 2010 dari http://www.agbnielsen.co.id.

AGBNielson Newsletter. (2008). Dewasa muda menonton paling sedikit. Diakses tanggal 14 September 2012 dari http://www.agbnielsen.net/where weare/dynPage.asp?lang=local\&id $=321 \&$ country $=$ Indonesia.

Agus Sudibyo. (2009). Kebebasan semu penjajahan baru di jagad media. Jakarta: Kompas Media Nusantara.

Alva Ayu Octavianesti. (2009). Pengaruh intensitas menonton televisi dan pendampingan orangtua terhadap imitasi perilaku kekerasan pada anak. Diakses tanggal 24 Februari 2011 dari http://eprints.undip.ac.id/22387/1 $\angle$ Alva_Ayu.pdf.

Diaz, C.F., Pelletier, C. M., \& Provenzo, E., Jr. (2006). Touch the future teach. Montreal: Pearson Education.

Eka Sulistyadewi. (1995). Hubungan antara intensitas menonton dengan ketertarikkan pada gimmick. Surabaya: Fisip Unair.

Gatut Priyowidodo. (2008). Menakar kekuatan dan keunggulan televisi lokal di era otonomi. Jurnal Ilmiah Scriptura, Vol. 2, No. $1: 56-62$.

Hamzah B. Uno. (2007). Teori motivasi $\mathcal{E}$ pengukurannya: analisis bidang pendidikan. Jakarta: Bumi Aksara.
Nielsen Newsletter. (2011). Data highlights: potensi penonton anak naik $17 \%$. Diakses tanggal 7 Maret 2013 dari http://www.agbnielsen.net/where weare/localnews.asp?id=0\&countr $\mathrm{y}=$ Indonesia\&newsty $\mathrm{pe}=\mathrm{L \& mode}=$ search\&year $=2011 \&$ month $=6 \&$ lang uage $=$ Bahasa $\% 20$ Indonesia .

Oemar Hamalik. (2008). Manajemen pengembangan kurikulum. Bandung: Remaja Rosda Karya.

Pusat Teknologi Informasi dan Komunikasi Pendidikan. (2007). Buku kerja tv-e. Jakarta: Pusat Teknologi Informasi dan Komunikasi Pendidikan. . (2007). Pedoman pemanfaatan siaran televisi edukasi. Jakarta: Pusat Teknologi Informasi dan Komunikasi Pendidikan.

Rusfadia Saktiyanti Jahja. \& Muhammad Irvan. (2006). Menilai tanggung jawab sosial televisi. Depok: Piramedia

Sardiman A. M. (2007). Interaksi dan motivasi belajar mengajar. Yogyakarta: Rajawali Pres.

Severin, W. J., \& Tankard, J. W., Jr. (2009). Teori komunikasi: sejarah, metode, dan terapan di dalam media massa. (Terjemahan Sugeng Hariyanto). Jakarta: Kencana.

Sri J Yunanto. (2004). Sumber belajar anak cerdas. Jakarta: Grasindo.

Sunardian Wirodono. (2005). Matikan tv-mu teror media televisi di Indonesia, Yogyakarta: Resist Book.

Tashakkori, A., \& Teddie, C. (2010). Handbook of mixed methods in social $\mathcal{E}$ behavioral research. (Terjemahan Daryanto). Yogyakarta: Pustaka Pelajar.

Yayasan Kesejahteraan Anak Indonesia. (2010). Jam belajar anak separuh jam nonton tv. Diakses tanggal 7 Maret 2013 dari http://www.ykai.net/ index.php?searchword=televisi + da $\underline{n+a n a k \& o r d e r i n g=n e w e s t \& s e a r c h p}$ $\underline{\text { hrase }=\text { all\&limit }=20 \& \text { option }=\text { com_s }}$ earch.

Yusufhadi Miarso. (2005). Menyemai benih teknologi pendidikan. Jakarta: Kencana 